\title{
Mental Alienation and African Identity: Exploring Historical Perspectives in Response to the Crises of African Societies
}

\author{
Tayo Raymond Ezekiel Eegunlusi \\ General Studies Department, Federal University of Technology, Akure, Nigeria \\ Email: kingadetayo@yahoo.com
}

How to cite this paper: Eegunlusi, T. R. E. (2017). Mental Alienation and African Identity: Exploring Historical Perspectives in Response to the Crises of African Societies. Open Journal of Philosophy, 7, 1-24. https://doi.org/10.4236/ojpp.2017.71001

Received: September 12, 2016

Accepted: January 20, 2017

Published: January 23, 2017

Copyright $\odot 2017$ by author and Scientific Research Publishing Inc. This work is licensed under the Creative Commons Attribution International License (CC BY 4.0).

http://creativecommons.org/licenses/by/4.0/

\section{Open Access}

\begin{abstract}
This paper argues that the colonially-motivated alienation of the African mind, which plays a major role in the moral crisis, corruption, war and anarchy on the African continent, makes the possibility of a true African identity uncertain. Writers often premise African identity on historical, cultural and psychological factors but these factors now appear to be weak constituents of this identity because of severe crisis facing the moral and communitarian foundations on which this identity rests. The present problem of the African state is dual-natured. First is that her rich moral heritage of dignity, discipline, diligence, faithfulness, honesty and sound integrity is being eroded. Second is that the spate of intolerance sweeping across some parts of Africa, resulting from unmitigated acceptance of alien western doctrines inappropriate for her culture, grossly infests her systems with a high level of intolerance and anarchy capable of making her social order like Hobbes' state of nature in which human life is "nasty, brutish and short." These situations, worst still, have horridly affected the meaningful and constructive development of the continent and rank her people among the poorest in the world, despite her rich natural and human resources. Using the critical and argumentative methods of empirical, conceptual and historical analysis, this paper explores the rich moral background of the Yorùbás, among other cultures, as case study, and urges a return to the moral ideals that once dominated and characterized African states.
\end{abstract}

\section{Keywords}

Africa, Colonialism, Domination, Identity, Mental Alienation, Morality, Yoruba 


\section{Introduction}

African identity has been premised on certain factors. These include historical, linguistic, cultural and psychological considerations. Though these factors hold important places in the description of the identity, they seem to be its weak constituents. What is called African identity seems to be somehow complex and obscure when given a thorough consideration. This is because a description of this identity is laced with ambiguity. This ambiguity emanates from the same factors upon which it is based. Historically, a lot of changes have happened as far as the linguistic, cultural and psychological leanings of African identity are concerned. For instance, considerations that were given to African identity during the precolonial period are not the same as during colonial and post-colonial periods. Colonialism has greatly influenced this identity. As colonialism thrived, it eroded the important fibres of this identity. Though Africans survived colonialism, the ushering in of neo-colonialism by post-colonialism made African identity so complex to deal with. Currently, the crises of the African continent have to do with the moral and communitarian structure on which this identity rests. This introduces two complex problems: first, the erosion of our heritage of moral discipline, dignity, diligence, faithfulness, honesty and sound integrity; second, unbearable level of conflicts emanating from intolerance due to unguarded acceptance of alien western doctrines that constitute threats to human and material resources on the African continent. These are capable of making Africa like Hobbes' (Hobbes, 2002: p. 58) state of nature in which human life is "solitary, poor, nasty, brutish, and short." As a result of these, a meaningful and constructive development of the continent is hampered and her people are rated among the poorest in the world. To address these issues and to urge a return to enviable moral ideals that once characterized African societies, this work explores the rich moral background of the Yorùbás as a case study, among other African societies. It employs philosophical methods of empirical, conceptual and historical analysis to tackle the challenges raised concerning African identity.

\section{The Question of African Identity}

In simple terms, the concept "identity" points to an identifying mark of something or that which depicts the character or nature of a particular thing. In this sense, certain identifying features show the structure of a thing. This definition will be our limit in defining identity in this work. The question "What is African identity?" is a difficult one. It may entail three things. First, the nature of African identity. One may ask if African identity is monolithic in nature. That is, is there a possibility of a universally acceptable African identity? What are our references to when talking of African identity? Are there particular identities within a universal identity such that when we make reference to African identity these particular identities will count as sufficient references? How do we reconcile the universal versus particular tension in description of African identity? Second, internalism and externalism perspectives to African identity. That is, outsider versus insider distinction in defining African identity. How do Africans define 
their identity and how do outsiders define it? Third, the definition of African identity as colonially-motivated changes in Africa's social relations. These changes determine and portray the current nature of the continent's identity. We will address the three showing how they affect the definition of African identity.

\subsection{The Nature of African Identity}

For decades, attempts have been made by writers to know the authentic nature of African identity, with each writer considering this identity from the perspective of his field of study. However, the idea of what constitutes identity for the African is complex, sometimes vacuous, intractable and somehow ambiguous in nature. In attempts to define African identity, several methods have been adopted. These include the anthropological, philosophical, sociological, linguistic/hermeneutic, historical, scientific, humanistic, psychological, geographical, religious, and statistical interpretative methods of inquiry. We, hence focus more on the philosophical and anthropological methods, considering the variegated nature of their inquiry which may take care of some of the concerns of the other methods mentioned here.

Obviously, one of the most dominant approaches to examining African identity is the anthropological dimension. Diop (1991: pp. 209-228; 1987: pp. 212235 ) is one of the figures known for this approach that construes African identity as having to do with people's origins, cultures and development. In discussing this, Africans' autochthony identity is given some consideration, which shows in some part of the analysis in the last paragraph above. An anthropological method engages a more comparative and historical dimension towards understanding what counts as a people's identity. What is attended to concerns African world-view, manner of life and the objects they interact with. An anthropological angle to addressing African identity is usually based on historical, cultural, linguistic and psychological factors (Diop, 1987: pp. 212-235). None of these factors have given sufficient description of what African identity is. Considering these factors separately, historical consideration makes the African to be thought of as linked to a time in his past by his history (as-Sadias, 1990). The idea of a common history is usually seen from the angle of certain historical trajectories. This is said to be making Africans to bond together anywhere. This may be a history of slavery, inter-tribal wars, common ancestry, and so on. By this, Africans are construed as prosecuting common ideals and goals and fostering brotherhood relations. This idea of a common history is also seen as influencing that of a common language. Though African languages are not uniform, Africans accept as part of their own one who descends from Africa and shares languages of the continent. Cultural factor is considered in this identity. This talks of things that are cultural elements and traits such as cultural artifacts, modes of greetings, trades, and so on. Taken together, all these evince psychological feelings in the African and give him a feeling of belonging. However, considering their points of convergence and divergence, what binds African communities 
and African settler communities in other nations outside Africa together seems to have a lot to do with their common history.

In dealing with the various claims based on the anthropological approach and other considerations from other disciplines, the philosophical method usually examines what the claims of the different fields are. Certain essential areas dominate philosophical discourses on the question of African identity. We will mention four core ones here: epistemological, moral, metaphysical and logical approaches. Epistemologically, African identity is assessed from the view of knowledge claims. Things such as oral texts, folk tales, chants, and so on, are included in this, since they are the sources of the African's knowledge claims. In later years, scholars such as Hallen and Sodipo (1997: pp. 40-80), and Horton (1967: pp. 164-166) attempted more rigorous analysis of the African knowledge claims. Metaphysically, African identity concerns the issues surrounding what Africans consider as reality. In the past, Africans are said not to be making real distinctions between physical and non-physical realities/worlds. By this, Africans are seen as never depersonalizing entities. What writers as Mbiti (1970: pp. 5-10) and Idowu (1962: pp. 18-148) consider as the distinguishing features of this metaphysical identity is the believe in the interaction of man with a non-human world. This includes interaction with deities, primordial divinities, ancestral spirits, and so on. These metaphysical realities have been adjudged to have affected an African's morality and shape his social conducts, as seen in Hallen's (2000) work and Kresse's (2003: pp. 312-315) review of this work. Moral claims were usually to the extent of the approval from the gods or the divinities. Sometimes when there are human agents involved in entrenching moral codes, they are regarded as divinities. For instance, the Yorùbá Oba was thought of as the deputy of the gods whose authority must never be questioned. Things are forbidden because the gods forbid them and violations of taboos attract sanctions from the gods/divinities. As such, metaphysics served as the underpinning of Africans' morality or moral claims. Logically, the pre-colonial African was not so concerned about logical reasoning or following logical rules but have preference for coherence of thoughts. In more recent times, there are debates in this area involving researchers such as Verran (2001: pp. 1-277). Verran recognized the difference between the logical perspectives in Africa and the western world. Examining logic in Yorùbá thought, she argued that western logic generalizes based on systematic analysis while Yorùbá logic deviates from this approach. It follows abstract thinking rather than the cultural events. Also, Kazeem (2010: pp. 1-14) has argued for certain logical elements discoverable in Yorùbá proverbs.

The way African identity has been discussed is as if it is a monolithic thing. This is the sense in which this work questions whether there is a universal African identity. What could be called a universal identity is difficult. In a loose sense, a universal African identity is possible but in a strict sense nothing unifies Africa to be called African identity. The factors often cited as common to African identity are just as common to other cultures as Africa. For instance, factors as marriage and belief in gods are as common to Africa as much as other races. 
In this strict sense, only particular identities exist. There are many identities in America as much as there are in Africa or Great Britain because of the different peoples resident in those cultures, results of colonialism, post-colonial migration, internal conflicts, peace resolutions, and several other factors. All these create diversity in the different areas. These point to the fact that only a consideration of a porous identity can be reasonable in our thinking about African identity. These examples shed light on this position. In the North of Nigeria there are traditional shan rumanche and Sharo marriage methods that are different from the marriage methods of the Yorùbás. Under the Sharo system, practiced by the Northern nomadic Fulanis, young men used to test their manhood by enduring beatings before the entire community while the girls they wished to betroth were present. During the beatings, the young men would endure severe beatings in the presence of the ladies. For a boy to betray his manhood indicated a sign of weakness and shame before a girl and the entire community. In the shan rumanche system, there were exchanges of gifts between the two young persons interested in each other. The man giving the first gift while the girl reciprocated.

Among the Yorùbás, the marriage method is different. Different literatures, including that of Chilota (2011: p. 51) shed light on the procedures involved in Yorùbá marriage. In the pre-colonial days and in the very early days of post-colonialism, many young people seeking marriage partners did so involving an intermediary called alarina. This may be a friend or a respected person close to the maid or her family who initiated the process of discussion between the couple or the bride's family. He is the one who relayed the suitor's intention to the family. In some cases, they may be a group of persons in cases of very important personalities. Where this intermediary succeeded, his work terminated and he became passive since his intention was not to control the couple but to initiate a conversation between the two and encourage their resolve to marry. Marriages were with the consent of the parents. On some occasions, parents from either side might veto their child's decision to marry the person he/she brought to them for various reasons such as incompetence, history of diseases in a lineage, unacceptable behaviour traits, and so on. Marriages were conducted with the idana process which is a traditional engagement in which both families were present and the groom's family brought different gifts and the bride price. The orientation behind this practice is to show that the lady had some dignity and that the family coming to ask her hand in marriage was competent enough to care for her. The people believe that the best gift a man can give is to give his daughter in marriage to another person. As such, their method of coming prostrate was to beg the bride's family to release their precious daughter to be married to the groom. In modern times, while still maintaining its structures, with the inclusion of certain aspects of westernisation in what constitutes it, this method of marriage has somehow fairly changed with post-colonialism in some communities (Atolagbe, 2012: pp. 158-161). As such, there are now instances of young men proposing marriages to ladies and marrying without their parents' consent. 
While some of the parents see this as an aberration some view it as part of the changing trends of modernism and seem content.

As the Yorùbá marriage method is different from the shan rumanche and the sharo, the practice in South-Eastern Nigeria was different. Among the Igbos, there is traditional male to female marriage. Under this, a man marries a woman and bears children through her. This is the most common type of marriage in the world. In certain cases, there were female husbands, in which case a woman married a woman for different purposes such as raising children for a deceased husband, protecting her lineage, and so on (Nwoko, 2012: pp. 69-79). The woman, thus, assumed the status of a man and performed the physical and spiritual duties and rites just like a man (Gaudio, 1998: pp. 116-117). In formalising the man to woman type of marriage, there are certain things that are put into consideration (Obi, 2013). These follow the three aspects of Igbo traditional man to woman marriage. The first part is the inquiring. At this stage, to marry, the suitor method is also used even though young men could propose to girls. If the girl is from a village different from that of the suitor, the elders of his family go to dialogue with the girl's family. Also, the young man willing to marry must show some sign of competence, which include his having money to foot the marriage bills and the resources to cater for his wife. Equally, the background of the two young persons would be checked for both families to be sure they are in safe hands and conditions. Marriage can be terminated at the level of inquiry if either or both families are dissatisfied with this inquiry's outcome. After settling the issue of a marriage partner, the families begin the process that actually leads to marriage. This brings us to the second stage: the introduction.

At the level of introduction, the man intending to marry a girl formally declares his intention by bringing wine to his bride-to-be's family in the company of his parents, siblings and friends. This is a way of telling other suitors to beware of coming near the girl. At the event, the girl's family and neighbours are present to witness the event and drink the wine. After the introduction, the girl can go to the groom's family to stay temporarily without having sexual contacts with her husband-to-be. The family will understudy her while she also understudies them to determine whether she would actually marry into the family (Olisah, 1963: pp. 16-17). At the end of her brief stay, if there is no complaint on both sides, the marital procedures could continue to the third stage which divides to two parts: the bride price and the Igba nkwu nyi (wine carrying). The two can be merged or done separately. At the stage of the bride price, the marriage is lawfully sealed (Ogbeide, 2011: pp. 103-110). The significance of this level is that the groom has formally informed the entire kindred or community that the girl is no longer free. In the future, if the girl decides not to marry the man again, he must compulsorily return the bride price with other items the tradition prescribes (Refugee Documentation Centre of Ireland, 2011). If the man is the one who decides to divorce his wife, he forfeits the bride price. In case the lady who becomes disinterested in the marriage decides to marry without returning the bride price, the children she bears for her new husband will be deemed to be belong- 
ing to the former husband until she repays the bride price. The wine carrying is done by the girl in the midst of the members of the kindred or, possibly, the entire community to identify her husband. All these are the processes culminating in the formal contracting of the marriage. The procedure is still largely followed.

In actual fact, any consideration of a monolithic identity seems to eliminate the possibilities of particular identities within Africa. As it is, there are many tribes and peoples making up Africa, who are affected by different histories. For instance, there are black Africans and there are non-black Africans. Examples of black African peoples include peoples along the West African coast, and some South African tribes, while modern Egypt, Tunisia and Algeria are examples of non-black Africans. Among these peoples, there are sub-tribes and peoples. In Southern Africa, there are black tribes and white peoples. The exodus of whites to South Africa because of trade opportunities and other considerations centuries back created a new identity different from the identity of the black Africans that were the aborigines of South Africa. While some of the blacks, say the $\mathrm{Zu}$ lus, pride in their ancestral affiliation to Chaka Zulu and other primordial leaders, some of the whites define their identity trying to debunk the migration hypothesis while some acknowledge this. Thus, there are white South Africans. Also, in many nations of the west that had colonial interactions with Africa are offspring of African people that are products of colonial and post-colonial miscegenation. These usually form part of the people often regarded as African diaspora. In these cases, the individuals determine which race they wish to belong to. While some reject links with being African others relish and pursue objectives towards determining their Africanness. In the North of Africa are Hausa/ Fulanis who spread Hausa language through the trans-Sahara trade (Library of Congress, 2008: pp. 1-5; Northern Nigeria, 2010). These people extend as far as Nigeria, Niger and Ghana. They speak the Chadic Hausa language and are predominantly Muslim majority. The Yorùbás of West Africa are mainly concentrated in Nigeria but the Yorùbá language is spoken as far as Dahomey in Benin Republic because of the conquests and establishment of the Oyo Empire. All the peoples along these regions share certain identities. In the pre-colonial era, the identities of the peoples of these regions were altered by trade and assimilating certain foreign ideas and traits that were not initially part of their cultures. For instance, the Yorùbás borrowed certain Hausa dresses because of intertribal interactions. Originally, these clothes originated from Arab influences on these North Africa peoples. Giving these different historical influences and differences in claims of identity, it becomes difficult to make sense of a universal or monolithic African identity in the sense in which writers describe African?

At this point, African identity is difficult since there is multiplicity of identity. Resulting from this situation are expressions like the Igbo identity, or Yorùbá identity, Fulani identity, and so on. This lack of uniformity suggests that there is no universally accepted African identity. If we decide to treat what is common within these identities as African identity, we cannot do so without excluding what other African tribes may count as important to their identities. Or better 
still, if we resolve to identify certain traits-historical, cultural, linguistic, etc.that are common to the continent, how do we successfully do this to identify or capture what the identity of the entire African nations and tribes is without omission of certain African peoples? These are the difficulties in defining this identity. In this instance, we may not have an African identity. This is the sense in which some writers talk of African identities.

\subsection{Internalism versus Externalism Conflict in African Identity}

Part of what makes the thought of an objective African identity difficult is the internalist versus externalist conflict in perceiving Africans. Table 1, as used by Harth (2009) in her "Representations of Africa in the Western News Media: Reinforcing Myths and Stereotypes," is a good portrayal of how Africa has been viewed externally since the pre-colonial era.

Table 1. Myths and stereotypes.

\begin{tabular}{|c|c|c|}
\hline & & List of myths \\
\hline$\#$ & Myth/stereotype & Description \\
\hline 1 & $\begin{array}{l}\text { Myth of Lack of } \\
\text { Progress }\end{array}$ & $\begin{array}{l}\text { This myth promotes the idea that Africans are isolated from global processes } \\
\text { and not-modern or-advanced, instead they are considered a-backward people. }\end{array}$ \\
\hline 2 & $\begin{array}{l}\text { Myth of the } \\
\text { Timeless Present }\end{array}$ & $\begin{array}{l}\text { This myth promotes the idea that Africa is a timeless place where everything } \\
\text { has always been a certain way (i.e. timeless). } \\
\text { Therefore, Africans are less evolved than others, specifically Europeans and Americans. }\end{array}$ \\
\hline 3 & $\begin{array}{l}\text { Myth of the } \\
\text { Primitive/Exotic }\end{array}$ & $\begin{array}{l}\text { The uses of the words primitive or exotic encompass a value judgment. } \\
\text { Their use means that there is something better (less primitive, more modern/advanced, smarter). } \\
\text { These are reference points generally used to demonstrate how one culture is better than } \\
\text { another (because I use a stove to boil water instead of an open fire does not make me } \\
\text { a better or smarter person). This is a problem of the language of description. } \\
\text { Similar problems occur with use of the words-tribe and-tribal. }\end{array}$ \\
\hline 4 & $\begin{array}{l}\text { Myth of } \\
\text { Tradition/Ceremony/Ritual }\end{array}$ & $\begin{array}{l}\text { This myth promotes the idea that African History is static rather than dynamic. } \\
\text { African traditions are viewed as always existing in an unchanging way. }\end{array}$ \\
\hline 5 & $\begin{array}{l}\text { Myth of African } \\
\text { Continuity }\end{array}$ & $\begin{array}{l}\text { Africa is often viewed as one country or one similar place. } \\
\text { However, over } 800 \text { different languages, wide cultural differences, } \\
\text { economic disparities and other differences dispute this myth. }\end{array}$ \\
\hline 6 & $\begin{array}{l}\text { Myth of the Lack } \\
\text { of History }\end{array}$ & $\begin{array}{l}\text { This myth states that Africa is a place without history and arises from colonization } \\
\text { efforts to justify racist policies that focused on constructing the idea that white people } \\
\text { brought history to Africans; it plays into the ideas that Africa is timeless and static. }\end{array}$ \\
\hline 7 & Geography Myths & $\begin{array}{l}\text { These vary but include the idea that Africa is mostly jungle or desert or that } \\
\text { there are no-modernl cities and that wild animals are-everywhere. }\end{array}$ \\
\hline 8 & Population Myths & $\begin{array}{l}\text { These vary but include the contradictions that Africa is either over-populated } \\
\text { (because Africans cannot restrain themselves from having children) } \\
\text { or it is under-populated because the people are poor and dying of hunger and AIDS. }\end{array}$ \\
\hline 9 & Poverty Myths & Many of these are specific to poverty in Africa, for example, the belief that all Africans are poor. \\
\hline 10 & $\begin{array}{l}\text { Hopelessness } \\
\text { Myth (i.e. Africa is a lost cause) }\end{array}$ & $\begin{array}{l}\text { There is so much violence, instability, corruption, poverty, disease, } \\
\text { and other problems that these issues can never be resolved; therefore, } \\
\text { it is not worth trying to help or concerning oneself with the continent. }\end{array}$ \\
\hline
\end{tabular}


The way Africans view themselves is different from the way outsiders view them. In recent times, what is responsible for this is our moral identity. The crisis of moral identity affects all other areas of consideration of African identity, whether political, historical, psychological, etc, and provokes philosophical arguments. Before colonialism, Africans' perception of themselves was based more on internal viewpoints. By this, they were able to form world views that directed the affairs of the continent. During and after colonialism, their perceptions became increasingly external in outlook. This latter status of Africans' perception of themselves is dominated by colonial influence. This shapes the way Africans define identity as being different from the way the outsiders define them. The Europeans, most especially, define African identity than we describe them. For instance, during colonialism, they saw Africans as apes and objects to be used and dumped. This shows in the chant "Apes obey!" to which Africans replied "Eh." This was used to motivate Africans to do manual labors. Unfortunately, Africans' replies depict their consenting to be apes. Long after independence of African countries, young people still use this chant to motivate themselves to do heavy tasks, such as lifting heavy objects. In describing this experience common to most African pupils who attended colonial and post-colonial African schools, Ojoniyi (2015: p. 631) made the following observations:

From my personal experiences of the relics of colonisation as a young boy growing up in Western Nigeria, I can give firsthand information of the subtle and unconscious damages of colonisation on the way Africans have come to perceive and understand themselves in relation to the crucial issue of identity. Such damages, especially of race and self perceptions, arise from the colonial masters' perceptions, creations and narrations of the natives which were uncritically accepted as the true representation of the black self. I remember that anytime there is a demanding task to perform, men will be assembled and one, giving a supposedly rousing command to motivate the men to a collective action will say in a loud voice: "eees sobey". "Eee sobey" is a corrupt form of "apes obey"! The colonial masters will yell at a group of blacks that have been assembled to carry out a task: “Apes obey"! So, "apes obey" is one of the several legacies of the colonial masters' ways of seeing the Africans and of dealing with them. They are as mammal as apes and gorillas, no more no less.

Showing the complexity and damaging effects of this kind of situation on the African mind, Ojoniyi (2015: pp. 631-632) said,

Unfortunately, as a result of this form of perception and narration, a subtle and an unconscious damage has taken place in the collective psyche of the people that from primary schools to secondary schools, teachers and instructors motivating us to carry out any challenging or daunting task are fond of yelling out as the "new educated masters", "apes obey". Those of us who try to "rebel" against being called "apes" by the new masters are met with cane and other forms of corporal punishments. The new masters dress and at- 
tempt to copy all the "noble" actions of their mentors including religion. The actions of our teachers, a carry-over of the colonial masters' superiority complex, can only complete the process of the progressive damages to the understanding and the perception of the black self of the students. The black self is also further damaged by the fact that the students are not allowed to communicate in their mother-tongue. The mother-tongue in the understanding of the new masters is a colloquial speech and, by implication, it is inferior, ignoble and totally unacceptable by any civilised mind! In front of every class during my primary and secondary school days till date one will always find it boldly written: "Vernacular Speaking in this Class is Prohibited!"

Apart from the above instances, our songs are dominated by colonial instincts and shape the way we view African identity. From simple to complex things, themes of colonial colouration reverberate across our lifestyles, the way we see African personalities, and so on. We have been unable to free ourselves from this domination. For instance, considering this nursery rhyme for African school children as they marched to their classes from their morning assemblies in the early post-colonial days, we get the picture painted by the whites of our colonial mental alienation which began before our independence:

Good morning Mr Joe

Good Morning to you all

I want to tell you about Ashanti war

The people of Ashanti they have no sense

O mao, o mao, o mao, mao, mao.

Another version of this rhyme says,

Good morning Mr Joe,

Good morning to you Sir,

We 've just come to tell you about Ashanti war,

Thee people of Ashanti they have not "pride"

When the guns are bursting they shout mewoo mewoo mewoo mewoo mewoo mewoo mewoo mewoo mewoo mewoo mewoo mewoo

As carryover of what happened in the transatlantic slave era (Manfra, 2008: p. 17), the above rhyme is one of several that the colonial masters taught African children, which mentally alienated them from the realities of their identification of their culture and the true picture of things for several decades after our independence. Many escaped the perspectives the whites created but several never did. Showing the internalist-externalist conflicting perspectives on African history, culture and civilization, New African (2006: pp. 66-69) chronicled an event that confronted western perspective on Africa and shed light on the inclination of some Africans towards a paradigm shift from the old colonial mental domination of the Africans. The magazine discussed Abu Boahen's February 3rd 1986 paper that pointed out the importance of Africans viewing themselves differently from the way the whites did (or still do). In addressing his audience during the 
public lecture, Boahen identified three books written from western perspectives that historians on African issues regard as "authoritative." The three books are $A$ History of the Gold Coast and Ashanti by W. Claridge (1915), History of the Gold Coast by W. F. Ward (1948) and Ghana, An Historical Interpretation by J. D. Fage (1961). Refuting the perspectives in the books, Boahen claimed that these writers wrote as outsiders with the mind of favouring the activities beneficial to Europe. In contrast, he claimed that his lecture focused on viewing African history as an African. That is, he saw things as Africans should view themselves.

In the colonial era, the whites saw Africans as means to achieving their ends. Many of them that came to Africa left with the mind to benefit their colonizing nations. Some of their literatures, as the ones cited by Boahen, reflect biased and derogatory perspectives that depict the marginalization of the Africans. This kind of perspective led some of the colonizers to debunk that Africans could exhibit their genius through artworks or have a sense of what it takes to be human and all sorts of demeaning outlooks (New African, 2006: pp. 18-19). As at now, many Africans have not stopped viewing themselves in these ways. Strictly speaking, Africans rate themselves so low in comparison to the whites because of colonial dominance. This compounded the already prevalent corrupt systems and unpleasant states of events on the continent. The aftermath of this is that some wish to-and actually did-abandon their motherland to settle in the western nations that have more organized systems, neglecting the continent's development. There are many African youths who daily make efforts to escape the shores of their countries so as to live in Europe and America and enjoy the comfort of those countries while forgetting that those nations took pain to develop. This some do through legal but most often arranged marriages that give them permits to stay in these countries. Even among intellectuals, who follow legal means, the brain drain is high. This questions whether our pursuit of knowledge has actually affected our perspectives to fashioning out an identity for the continent. It seems that the colonizers colonization of our mentality has made us disadvantaged despite our learning. Many others who stay back in Africa see their lack of opportunity to travel and escape the shores of Africa as serious disadvantage and resolve to pursue their self-interests without giving serious thought to public interests and developmental necessities. At the same time, many are passive while only a handful is willing to do anything. But, sad to say, these few are "lone rangers" and unwanted voices in the midst of the multitude. This makes the case pathetic. Obviously, all the above considerations contribute to our assessing or seeking an understanding of what African identity is. In some cases, the issues raised obscure or make this identity more ambiguous such that rather than get a good description of the identity we get farther from its reality.

\subsection{Change and the Crisis of Identity}

The change brought about by colonialism plays a great role in the difficulty of the description of African identity. In the pre-colonial era, it was not so difficult to pin down what may count as African identity (Cokley, 2005: pp. 517-526). 
The small nature of some communities and the cohesiveness of their systems made this easy. However, the changes that Africans experienced in the colonial era began with the indoctrination of the Africans by the whites. This indoctrination started through western education. This began a spate of strong mental erasure of certain African practices and manners of doing things and their replacement with the colonizers' ways of doing things. According to David C. Woolman (2001: p. 27), "Education should function as an agency of cultural transmission as well as change; it should also reflect the dynamic process of nation building that is continually being modified by new conditions." The western education, in certain situations, pitched the people against some of their leaders and caused serious conflicts for these societies. With education, foundations of African traditional beliefs, orientations, governmental institutions and world views became questioned. At the same time, the gradual erosion of these structures had kicked off for the triumph of western imperial domination. Africa's traditional political and economic structures became eroded, alongside other important forms of identity. In a short while, the once strong moral foundation on which her systems were built became weak and shaky only to later finally collapse in the post colonial era. As at now, there are social, moral, economic, psychological, etc, changes that trail the collapse of the moral basis of our traditional systems.

It is now increasingly doubtful of what to make of African identity. To say the least is to affirm that colonialism has whittled down the strength of this identity. Modern African societies can no longer boast of the sound moral virtues they pride in. It was easy for the traditional Africans to allude to the fear of the deities as a reason why certain moral standards must not be violated. In modern Africa, there seems to be no fear of any deity. As such, lawlessness prevails. This shows that the metaphysical elements on which African morality rests is shaky and disbelieved by many who perpetrate the lawless acts (Hallen, 2004: pp. 296-303; Taiwo, 2004: pp. 304-312: Gbadegesin, 2004: pp. 312-323). While many sincere others may consider objectionable the metaphysical realities on which African morality is built and encourage a development of morality for its humanism, the failure of the moral system of the continent should not have been allowed. Given the failure of the African moral system based on metaphysical justification, an epistemic justification of African moral claims may also be facing the same problems. As at now, Africans seem to be basing their lifestyles on an epistemic justification of morality that is alien to the African continent. This on its own introduces some incoherence in our moral thought system and defeats the purpose of morality on the continent. This points to the fact that the identity traditional Africans pride in is no longer what it used to be. This absence of a sense of autochthony identity on the continent seems to be the bedrock of our identity crisis as a people. At this point, to avoid the possibilities of unending analyses on what the nature of African identity is, we hence adopt a loose approach to African identity and treat it as that which incorporates it particularistic sense without necessarily taking note of the complex issues raised above. 


\section{Colonialism, Neo-Colonialism and the Alienation of the African Mind}

Colonially, the African is alienated. This alienation has several dimensions such as political, moral, economical, and so on. The systems of government, the moral behaviour we now imbibe, the economic policies we follow, and so on, are motivated and dominated by the west. The root of these is our mental alienation by colonial policies. This mental alienation was imposed on us through western education. Through this, Africans' colonizers imposed their cultural systems, values and ideals on the Africans. This was done through imposing their languages on the continent. Obviously, this is the most dominant approach to impose alien values on a people. Our colonizers introduced their languages and cultures. In some part of Africa, the French colonizers attempted making us to follow their cultures of assimilation. By this, what was introduced was not just the language but their manners of life which include their modes of dressing, eating, and so on. This was total colonization. As at now, our thoughts are dominated by what their linguistic terminologies direct. We do things through their languages and communicate our ideas through them. This became our main medium of expressing our ideas. As such, languages as French, Portuguese and English dominate our daily affairs. This indicates that, epistemologically, Africans are alienated by colonialism. Initially, colonialism imposed these languages on us and we are forced to assimilate western cultures. However, by the time colonialism ended, the damage was done. We seem to be forever alienated, with our values mortgaged and our economy damaged. In this light, post-colonialism gave rise to neo-colonialism. The mental alienation in the neo-colonial era is worst. The colonial structures gave strength to neo-colonialism. Let us shed more light on these comments in the following paragraphs.

There are issues that strengthen colonial activities in Africa. According to Devlin \& Grafton (1998: p. 2), one is a relentless drive to explore more Africa lands so as to gain from the continent's resources. Another factor which interweaves with this is the partition of Africa by the colonial powers in the $1800 \mathrm{~s}$. This made Africa to be conceived as a geographical entity only good for furthering European colonial interests and promoting European imperialist economy. At the same time, Africans were seen as mere tools for achieving European colonial interests. As much as they took most part of Africa captive, they also used their peoples as emissaries and tools in their armies to fight the regions they wished to conquer through different ploys. Kingdoms conquered through such means included the Ashanti kingdom in modern day Ghana, the Oyo Empire in South-Western Nigeria, Sokoto Calipahte, Benin Kingdom and the kingdom of Jaja of Opobo in modern day South-Eastern Nigeria (Rotimi \& Ogen, 2008: pp. 48-56). These kingdoms' rulers were, most of the time, sacked and their artifacts and resources looted. Thus, priceless African resources and artifacts found their ways to Europe and were used to develop the place while Africans were deceived into believing that European cultures and governance policies were best. Though many Africans did not agree with these postulations, they could do little to 
change things because of the supreme military strength of the colonial powers at that time. Thus, as shown by Fanon (1986: pp. 17-27), Africans suffered more psychological damage than was necessary and mourned the loss of their heritage in silence. If the colonial partition of Africa damaged the psychological and cultural image of the African people, colonial domination did worst. It gave the people more of a negative orientation and mental estrangement. Besides, it pitched Africans against themselves such that the internal wrangling after colonial rule left worst forms of governments and regimes of corruption on the continent. One area that showcases European colonial mental alienation of Africans is the practice of British indirect rule system. Mahmood Mamdani (1996: pp. 145-150), observed that British indirect rule policies in Africa were more prevalent in Nigeria and Kenya because of Frederick Lord Lugard's activities and writings on indirect rule (Mamdani, 2000: pp. 43-45).

Taking Nigeria as a case study, the problems created by indirect rule system remain a negative colonial structure and an undeserved legacy the nation has been unable to free herself from since decades of independence. Olukoshi and Liisa (1996: p. 40) are right to have observed that "decomposition and recomposition" hinder any meaningful post-colonial integration. As at the time the British colonial powers in Nigeria under Lugard's leadership convinced the leaders of the nation's North to adopt colonial rule in the early twentieth century they were finding difficult the governance of the entire nation by a direct rule system. Prior to their arrival were strong forms of indigenous governments among the people that later formed Nigeria. In the Southwest, there were well-established monarchical structures similar to the British monarchical system that made direct rule easy. Besides, the Southwest had been involved in the trans-Atlantic slave trade and had long interaction with the colonial powers. This formed part of why their resistance of the whites did not last and they submitted to direct rule. Following what Isichei (1978: pp. 71-75) described as democratic, the South-Eastern system was acephalous in nature and was weakened by forceful imposition of direct rule. Initially, particularly, it was uneasy for the whites to rule the Igbos because of a lack of an established central traditional structure. The people were governed more by a loose but strong system in which the family heads serve as village leaders. The age grades and the priests were also active. All these three groups were decision makers and played vital roles in directing the affairs of the various Igbo communities. From time immemorial, crowned leadership was foreign to the Igbos. One or two of their towns where there were crowned traditional rulers were the areas close to other kingdoms with crowned kings. As a result, the cultures of those kingdoms influenced them. For instance, Onitsha where there is an Obi till date is close to Benin Kingdom and adopted the Benin style or ruling. However, these crowned leaders could only exercise minimal leadership control because the acephalous Igbo governance system gives them little power. Because of lack of a unified Igbo governance structure, colonial ploys to penetrate them initially failed. The colonial powers eventually penetrated the South-Eastern people's governance system by luring their mem- 
bers to their services and introducing direct rule. Other minor tribes in the East (South-East and South-South together) were not so successful in resisting colonial domination and direct rule.

The North had a long history of Islamic rule and contact with the Arabs through the trans-Sahara trade. Three major tribes dominated the North: the Hausas, the Fulanis and the Kanuris. As at the time the colonizers arrived, the Sokoto Calipahte established by Usman Dan Fodio was still strong there. After the overthrow of the Calphate, it was difficult for these colonizers to rule the people directly and easily unless they engaged the already established Islamic governance structures in the North. The dominance of Arabian/Islamic culture made the people listened more to and obey their leaders than outsiders. Apart from having trade links with Asia, North Africa and Southern Nigeria, as shown by Ukiwo (2005: p. 6), the North also had an effective system of taxation which the British really needed. Apart from this, their political structure had so wellorganised divisions that could facilitate trade and more benefits for the colonial government. Considering these factors, the British decided to introduce indirect rule to them to make their operations easy in the region. By this, they could control trade and exert other forms of influence without directly governing the people or incurring unnecessary governance expenses. Thus, the loyalty of the North to the British became stronger.

Through introduction of different colonial policies, the thoughts of the Northern and Southern (South-Eastern, South-Western and South-Southern) peoples became diametrically opposed with an unnecessary competition setting in. As could be gleaned from a work by Ajala (2009: pp. 3-13), this set the stage for the crisis of leadership that came in later years from which the nation has been unable to free herself. For instance, when a South-born nationalists founded the Nigerian Youth Movement in 1934 in reaction to the unfavourable conducts of the colonialists in relation to Nigeria's educational system, it was rejected by the North. Also, after Obafemi Awolowo, a Southerner founded the Egbe Omo Oduduwa in 1944, the North established the Jamiyar Mutanem Arewa in reaction to this. As deducible from Martineau's (2006: p. 216) article, these events show that indirect rule system really divided the peoples along interest lines. One negative result of this kind of situation is that efforts to gain independence from Britain by the Nigerian nationalists from the South were hampered by the activities of the nationalists from the North between 1948 and 1959.

After independence, a major crisis that persists as a result of the governance pattern of British colonial administration is that of Nigerian tribes' unceasing agitation for unreserved pursuit of tribal interests and, covertly, pursuits of self-interests by those in power. Besides, the orientation imbibed by some of the tribes makes them think of themselves as possessing hegemonic dominance over others in certain areas. For instance, the people of the North consider themselves as those who are "born to rule". For several years, through the military, this mindset did not make them relinquish power to any other tribe. Obviously, after years of power tussle between the peoples, in the pre-independence power expe- 
riments, the British quit the governance stage. The perceived more enlightened and intellectually aggressive South-West was not in power because of the possibility of strong resistance to British colonial legacies and post-colonial policies. The most prominent of their leaders were, at best, in the regional governments or constituted oppositions in the parliament. Whereas, in the post independence parliamentary system practiced by Nigeria between 1960 and 1966, the North produced the only Head of Government leaving the East with the position of a Head of State. As far as that system was concerned, the North was holding the most powerful position while the East was only the ceremonial head. Apart from this, between 1966 and 2016, the North produced nine of the nations Heads of State in roughly fourteen regimes while the East and South-West combined produced only four, if we take exception to the parliamentary system of 1960 to 1963 and the short-lived operation of the republican constitution from 19631966. Taken together, the North ruled Nigeria for forty one of the nation's fiftysix years of independence while the South-West and the East only ruled for fifteen years. Where the North could not get power easily, efforts were made to seize power through military coups (Ukiwo, 2005: pp. 7-10). Out of the nation's seven military regimes in almost thirty years, the North had six Heads of State with the East and the South-West having three out of which two completed the terms of two North-born Heads of State in a total of almost four years. The only East-born Head of State deposed by the North in a military coup spent just six months. Over the years, the intense competitions between the North and the South, as a result of British indirect rule policies, have not assuaged (USAID, 2006: pp. 20-24). Unfortunately, the volatile systems created by the colonial powers, especially the British, have been accompanied by untold immoral practices and all forms of dastardly acts.

Generally, in most part of Africa, the colonial policies left the most volatile structures with the negative impacts. Unfortunately, our people now use this structure to plunge the continent into further crises. One of the most prevalent aspects of these crises is moral crisis which has caused us untold hardship, poverty and emotional trauma. For instance, institutional or endemic corruption is part of operations in African nations. This moral crisis leaves room for people to suffer on the continent as people who are custodians of national treasuries divert public funds for personal interests or mismanage funds. Apart from this, moral crisis has plunged us into political and economic crisis. In recent times, the adoption of western media by the Middle Eastern and oriental nations contributes to these crises. In most part of Africa, broadcast of revolutionary activities from the Middle East and Asia have promoted alien ideas that introduce regimes of violence to African nations (Heydemann, 2013: pp. 59-72). Springing up are ethnic militias groups such as the Boko Haram and Ansaru which are imitators of similar violent groups in other areas of the world. As at now, these groups constitute themselves to terrorist groups that engage African nations in internal war and profess incendiary militant ideas that lure youths who believe in their activities. Unfortunately, their activities result in more deaths and kidnappings 
of innocent persons. One problem we have in Africa, which is why we are neck deep in moral, political, psychological and economical crises is our wholesale imbibing of western ideas which are not good for our continent's development (Ibeanu, 1997: p. 3). Long after the colonial powers ruled us, we are yet to possess the mind to rule ourselves. We are still mentally colonized and act as if under colonial rule. However, if we do not embark on mental de-alienation, we risk generational identity crises.

\section{Mental De-Alienation}

To achieve mental delineation, possible alternatives are open to us. First, to completely reject all foreign ideas. This will be difficult and cause more crises than imagined. We have debated that colonial domination gave rise to escalated moral deficiencies in Africa, although we do not deny that moral problems are part of the existence of every society, since humans are naturally fallible. There were delinquent, moral and corrupt Africans before European colonialism but the societies had mechanisms for dealing with the problems such that they were able to promote moral sanctity in the communities. Though in modern parlance, some of the approaches may be considered primitive and barbaric. In some African societies of the past, people who stole were subject to varying types of punishments. Some were ostracized or banished while heavy fines were imposed on others. For instance, those who slept with other people's wives or husbands were paraded naked. On most occasions, the punishments were enforced to cause such people to be ashamed and deter others from engaging in such immoral acts. In some cases where they could not locate a perpetrator they invoked curses believing that their gods would punish the person. This recourse to metaphysical power further instills fear in the hearts of the people. With the liberty that came with colonialism seems to have appeared an incontrollable dwindling of the Africa traditional modes of dealing with moral problems. On the continent today are people who embezzle funds belonging to their nations and take advantage of legal loopholes to win court cases and keep what they stole to the detriment of millions of others. In cases where some of the individuals fail to escape in legal battles, plea bargaining or out of court settlements by their friends see them releasing part of their national loots to keep the rest. These practices reveal the extent of the corruption on the continent. However, despite these modern moral problems, we cannot completely reject all foreign western ideas. There are aspects that are useful for our growth and development.

The second option we have is to consider an integration of western and African ideas. (Obviously, if we have argued that western cultures have certain good aspects, it would be unreasonable to conclude that a merger of Africa and western ideas is unreasonable.) For decades, post-colonial African leaders adopted this option, but to the detriment of African ideas necessary for the continent's growth. In cases where they succeeded in merging these ideals, as deducible from Biney's (2008: pp. 129-131) observation of Nkrumah, personal moral failures water down the strength of the messages they were trying to pass across to 
other Africans and cause the people to be further alienated as they turn to other alien ideas for consolation. In as much as we allow foreign ideas, we must always look inwards to develop. One obvious reason for the moral decline in Africa is the abandonment of the African ideals necessary for African growth. An increasing concentration on African ideals will help us in the process of mental de-alienation. Because of mental de-alienation, we are only colonially independent in principle but not in reality. Mental de-alienation will help us to assert our true independence and growth. As at now, in the comity of nations, Africa is a laughing stock. We are ridiculed and disdained because of our moral decadence that emanated from a negative colonial mindset.

In confronting the moral challenges of the African continent, the remaining part of this work concentrates on applying certain Yorùbá moral values to reflect on the importance of an African's applying of African moral ideals to African growth and development. We will focus on four main areas that need to be affected by mental de-alienation of the African. First, the importance of an African person's personal development and personal valuation and evaluation. Since personal assessment may enhance meaningful existence, this aspect concerns the development of his/her character and the value he places on himself. Second, the importance of the community and the individual African's role in it. Third, the importance of the self in relation to the others. This will strengthen the individual's role in the community and in meaningful relationship with others. Fourth, the importance of an African's/Africa's heritage. This talk of the legacies each person wishes to leave behind that will immortalize him and the way we preserve the continent for future generations. We will treat the first separately and the others together. Mental de-alienation is the complete reorientation of the African to think of things that can make for his personal growth and that of his continent. According to Nkrumah (1970: pp. 78-79) man has a central role to play in Africa's freedom. This requires two aims:

First, the restitution of the egalitarianism of human society, and, second, the logistic mobilization of all our resources towards the attainment of that restitution. The philosophy that must stand behind this social revolution is that which I have once referred to as philosophical consciencism; consciencism is the map in intellectual terms of the disposition of forces which will enable African society to digest the Western and the Islamic and the EuroChristian elements in Africa, and develop them in such a way that they fit into the African personality. The African personality is itself defined by the cluster of humanist principles which underlie the traditional African society. Philosophical consciencism is that philosophical standpoint which, taking its start from the present content of the African conscience, indicates the way in which progress is forged out of the conflict in that conscience.

The idea of consciencism which forms Nkrumahs Triple Heritage Thesis which Ali Mazrui later developed, emphasised this role of human development and freedom in developing the African continent. Before colonialism, Africans 
had ways of training their people to develop their societies. This was done by allowing the individual to grow within the communal settings of African societies. Except in rare cases, the survival of the society was taken as necessary for the survival of the individual. As such, the individual was allowed to develop morally in conformity to laid down standards. Thus, the moral development of the individual was central to the development of his personality which, consequently, was important for the development of the society. This moral development determines the way the society viewed individuals and the responsibilities they commit to them.

Towards achieving character development, the Yorùbás make distinction between an Omoluabi (a morally virtuous person) and a non-Omoluabi. The former is expected to possess certain traits such as dignity, discipline, diligence, faithfulness, honesty and sound integrity. He is not an Omolulabi who misbehaves and acts in ways not socially acceptable to the society. This category includes deviants, youngsters who despise elders, thieves, and so on. In short, anyone who is considered a social anomaly is a non-Omoluabi. The society may not impose any punishment on a non-Omoluabi if his character is not really injurious to anyone/community. For instance, a man who beats his child against the plea of an elder may not be an Omoluabi for disrespecting an elder but no one may rebuke him for chastising his child. Also, a person who disrupts the peace of the society is not an Omoluabi and may be subjected to ridicule or varying punishments such as imprisonment or excommunication. In certain cases, a non-Omoluabi may be avoided by people or made to face sanctions if his character becomes a bad influence on the community. For instance, a thief may be made to pay heavy fines, be stigmatized and avoided against Yorùbás' belief that "Ení jalè leèkan tó dârán bori, bó t’ogún odún tó dârán bora aso olè ló dâ bora." Interpreted, this means whoever steals once and covers himself in royal apparel is still covered by the apparel of a thief. The apparel of a thief here is social stigma. The thief may never be trusted. This Yorùbá expression is not limited to issues of stealing but may also be applied to general indiscipline among individuals. By this saying, those who cannot be trusted morally will be side-tracked while those who have sound moral character are allowed to carry out duties that require trustworthiness. The Yorùbás value sound moral virtue. The texts of these recitations buttress the point we are trying to make here:

Yorùbá

1. Eéfín nìwà, rírú ló ń rú

Ėnìyàn gbokèèrè níyì

Sún móni là á mòse eni

İwà kìi foníwà sílè

İwà omo ló ń somo lórúko

Ará dára ó ku ìwà

Óri dára ó ku ide

Esè dára ó ku bàtà

B’énìyàn dára tí kò n’iwà
English

Character is a smoke, it will always show A person has prestige when perceived afar off To be near is to know his conducts

Character never leaves its owner

A child's character gives him a name

The body is beautiful but for character

The head is good but for crown

The foot is good but for shoes

If someone is beautiful but lacks character 
Ó pàdánù ohun ribi ribi

İwà lewà omo ènìyàn
He has lost something great

Character is a man's beauty

The above saying talks about the need for the individual to develop moral virtues. The one below emphasizes the importance of hard work. Diligence is taken as a moral virtue.

Yorùbá

2. Tójú ìwà re òré è mi

Olá a máa sí lo ní ilé eni

Ewà a sì ti ipa àì̀àn di ohun àbùkù

Olówó òní í d'olòsì bó d'òla
English

My friend, take care of your character wealth can depart from a person's house

Sickness can corrupt beauty

The wealthy today can

become poor tomorrow

Sùgbón ìwà ní í fún ni níyì tí kì í tán títí But character can give lasting honor

Owó ò jé ňkan fún ni

Money is really nothing

İwà lewà omo ènìyàn

Character is a man's beauty

Yorùbá

3. Isé lòògùn İsé

Múra sí isé òré è mi

Isé la fi ń di eni gíga

Bí a kò bá r’éni fèhìn tì bí òle làárí

Bí a kò bá r'éni gbékè lé

A tera mósé eni

İyá re lè lówó lówó

Kí bàbá re lésin ilé kan

Tí o bá g'bójú léwon

O té tán ni mo so fún o

Ohun tí a kò bá jìyà fún

Sé kìi lè é tójó

Ohun t'abá fara sisé fún ní tó lówó eni What we labor hard to get lasts with us Apá lará ìgúnpá n’iyèkan

English

Work is an antidote to poverty

Work hard my friend

It is through work that one

becomes highly placed

If there is no one to lean on we appear to lazy

If there is no one to depend on the best option is to work hard Your mother may be wealthy Your father may own a giant house If you rely on them You have set yourself up for shame What we never labor for does not last Our arms are our family members and our shoulders are our kinsmen

The last one above was not concluded (there are about sixteen lines left). However, apart from their central theme, which admonishes a person's careful development of his character, the above lines have other themes that point to the central theme. These sub-themes include the vanity of trusting in beauty and wealth, the folly of frivolities and dependence on other's properties, the dignity of labor, the wisdom of making choices to own private properties, the significance of getting wealth by honorable means and the stupidity of making fun of hardwork. In modern Africa, those who hold responsibilities are those we know to be corrupt and place little value on the development of sound virtues. This is why the continent is in moral conflict. Unfortunately, on many occasions, those 
who loot national treasuries are the ones that are now celebrated. What misses here is individuals' recognition of their importance in community development. In relation to the community, the Yorùbás have proverbs and sayings that focus on community development. For instance, the expression "İmàdò ìbá se bí elédèè a b’àlú jé" (Had the warthog behaved like the domestic pig it would have spoilt a whole town) is usually directed at a rebuke of someone who misbehaves whose lifestyle may negatively affect everyone in the community. Another is "Ení gb’èèbù ikà omo rè ni yóò wu je" (whoever plants an evil seedling leaves it for his children to eat). This proverb invokes a sense of retribution that is used to caution those who sow evil seeds in the community or in relation to others. This proverb is significant in that it points out that human actions have consequences, which may take any form. In the past, those who wished to perpetrate wrong acts in whatever form were able to behave well when they reflect on the above and other similar expressions which constitute the light through which individuals in Africa assess the importance of their actions.

Another proverb is "Àgbà tó so àgbàdo módi ló so ara rè di aláwàdà adìye" (he elder who tied a corncob around his waist makes himself a laughing stock for chickens). This proverb depicts the importance of proper conduct within the society so as not to become ridiculed. We need to de-alienate ourselves mentally by giving attention to the epistemic constituents and elements of African proverbs, axioms, folklores, and so on, aimed at moral rectitude and how to and apply them to gain moral relevance. In the past, attentions to these orientated us towards living the good life. In the modern period, we care less about the moral lessons of the African culture and crises result. We need to look inwards and develop the orientation that can help us to exhibit proper moral conduct so as not to become ridiculed in the comity of nations. The present incessant brigandage on the continent and the prevalent corrupt systems ridicule us in the mind of many nations. We need to embark on mental de-alienation. A Yorùbá saying affirms: "Teni ni teni, t'àkísà ni t’ààtàn" (What is yours is yours, rags belong to the dunghill). Africans need to re-identify with the African continent and prioritize it as their own. Nothing stops us from jettisoning the wrong things we picked as results of colonialism and neo-colonial tendencies. This is when we can leave good legacies for our children and have a continent that is not embroiled in crisis of identity.

\section{Conclusion}

In conclusion, this work argued that the identity of modern Africa is confusing because of her moral deficiencies and prevalent state of corruption that are colonially motivated. We have not argued that African identity is not knowable but that it seems confusing and difficult to understand given certain factors concerning the conflict of universality versus particularity in this identity and the moral confusion in the post-colonial era that makes the identity have a negative outlook. However, as a way of overcoming the moral crises that create a negative image for the continent, the work urges a return to certain Africa traditional 
moral ideals, which may still be found in proverbs, sayings, folklores, and so on, that can help in regulating people's conducts and give the continent a positive image and make her people to be regarded as trustworthy.

\section{Acknowledgements}

This work was motivated by the Toyin Falola conference held in Ibadan, Nigeria, in July, 2013. I sincerely appreciate Onyibor Marcel for his suggestions, especially in helping to clarify the aspect on Igbo marriage. I also thank Lawrence Bamikole, my undergraduate teacher, for bringing the issues involved in Nkrumah's Triple Heritage Thesis to my attention.

\section{References}

Ajala, A. S. (2009). The Yoruba Nationalist Movements, Ethnic Politics and Violence: A Creation from Historical Consciousness and Socio-Political Space in South-Western Nigeria. Working Paper No. 1.

as-Sadias, A. R. (1990). Tarikh s Sudan. The History of the Land of the Blacks. Sudan: Sankore."

Atolagbe, A. (2012). Semiotics and Language Interlarding in Yoruba Traditional Wedding Bilingual Discourse. Journal of English and Literature, 3, 158-165.

Biney, A. (2008). The Legacy of Kwame Nkrumah in Retrospect. The Journal of Pan African Studies, 2, 129-135.

Chilota, E. J. (2011). Marriage Culture in Yoruba Land, Nigeria, Africa. Khazar Journal of Humanities and Social Sciences, 4, 51-60. https://doi.org/10.5782/2223-2621.2011.14.3.51

Cokley, K. O. (2005). Racial(ized) Identity, Ethnic Identity, and Afrocentric Values: Conceptual and Methodological Challenges in Understanding African American Identity. Journal of Counseling Psychology, 52, 517-526. https://doi.org/10.1037/0022-0167.52.4.517

Devlin, R. A., \& Grafton, R. Q. (1998). Economic Rights and Environmental Wrongs. Cheltenham: Edward Elgar. https://doi.org/10.4337/9781840647631

Diop, C. A. (1991). Civilization or Barbarism: An Authentic Anthropology. Bristol: Lawrence Hill Books.

Diop, C. A. (1987). Precolonial Black Africa: A Comparative Study of the Precolonial Political and Social Systems of Europe and Black Africa from Antiquity to the Formation of Modern States. Salemson, H. J,. Trans., Bristol: Lawrence Hill Books.

Fanon, F. (1986). Black Skin White Masks. London: Pluto Press.

Gbadegesin, G. (2004). Toward a Theory of Destiny. In K. Wiredu (Ed.), A Companion to African Philosophy (pp. 312-323). Hoboken, NJ: Blackwell.

Hallen, B. (2000) The Good, the Bad and the Beautiful: Discourses about Values in Yoruba Culture. Bloomington, IN: Indiana University Press.

Hallen, B. (2004). Yoruba Moral Epistemology. In K. Wiredu (Ed.), A Companion to African Philosophy (pp. 296-303). Hoboken, NJ: Blackwell.

Hallen, B., \& Sodipo, J. O. (1997). An Africa Epistemology: The Knowledge-Belief Distinction and Yoruba Discourse. In B. Hallen, \& J. Olubi Sodipo (Eds.), Knowledge, Belief and Witchcraft (pp. 40-80). Redwood City, CA: Stanford University Press.

Harth, A. E (2009). Representations of Africa in the Western News Media: Reinforcing Myths and Stereotypes (pp. 1-67). Master's Thesis, Tiffin, OH: Tiffin University. 
Heydemann, S. (2013). Tracking the "Arab Spring": Syria and the Future of AuthorItarianism. Journal of Democracy, 24, 59-72. https://doi.org/10.1353/jod.2013.0067

Hobbes, T. (2002). Leviathan. The Project Gutenberg EBook of Leviathan.

Horton, R. (1967). African Traditional Thought and Western Science. Africa, 37, 155-187. https://doi.org/10.2307/1158253

Ibeanu, O. (1997). Oil, Conflict and Security in Rural Nigeria: Issues in the Ogoni Crisis (pp. 3-8). Occasional Paper Series 1, African Association of Political Science.

Idowu, B. (1962). Olodumare: God in Yoruba Belief. London: Longman.

Refugee Documentation Centre of Ireland (2011). Information on Bride Prices/Dowries in the Igbo Tradition/Customs? Nigeria.

Isichei, E. (1978). Igbo Worlds an Anthology of Oral Histories and Historical Descriptions. Philadelphia, PA: Institute for the Study of Human Issues.

Kazeem, F. A. (2010). Logic in Yoruba Proverbs. Itupale: Online Journal of African Studies, 2, 1-14.

Kresse, K. (2003). The Good, the Bad and the Beautiful: Discourse about Values in Yoruba Culture by Barry Hallen. Journal of International Africa Institute, 73, 312-318. https://doi.org/10.3366/afr.2003.73.2.312

Library of Congress (2008). Federal Research Division, Country Profile (pp. 1-5). Nigeria.

Mamdani, M. (1996). Indirect Rule, Civil Society, and Ethnicity: The African Dilemma. Social Justice, 23, 145-162.

Mamdani, M. (2000). Indirect Rule and the Struggle for Democracy: A Response to Bridget O’Laughlin. African Affairs, 99, 43-50. https://doi.org/10.1093/afraf/99.394.43

Manfra, M. M. (2008). A Teacher's Guide to the Signet Classics Edition of Harriet Jacobs's Incidents in the Life of a Slave Girl. London: Penguin.

Martineau, J. L. (2006). Yoruába Nationalism and the Reshaping of Obaship. In T. Falola, \& A. Genova (Eds.), Yoruba Identities and Power Politics. Rochester: University of Rochester Press.

Mbiti, J. S. (1970). African Religions and Philosophy. London: Heinemann.

New African (2006). (pp. 1-75).

Nkrumah, K. (1970). Consciencism: Philosophy and Ideology for De-Colonization. USA.

Northern Nigeria (2010). Background to Conflict Crisis' Group Africa Report No. 168 (pp. 1-4).

Nwoko, K. C. (2012). Female Husbands in Igbo Land: Southeast Nigeria. The Journal of Pan African Studies, 5, 69-79.

Obi, C. A. (2013). Marriage among the Igbo of Nigeria. http://www.afrikaworld.net/afrel/igbo-marriage.htm

Ogbeide, O. V. (2011). Of Wine Carrying and Bridal Train: A Portrayal of Traditional Igbo Marriage in Elechi Amadi's the Concubine and the Slave. Journal of Sociology and Social Anthropology, 2, 103-110.

Ojoniyi, B. (2015). Education and the Intentionality of a Performing Arts Educator in Nigeria. American Journal of Educational Research, 3, 630-640.

Olisah, O. (1963). Ibo Native Law and Custom. Onitsha: Okenwa Publications.

Olukoshi, A. O., \& Liisa, L. (1996). Challenges to Nation State in Africa, Nordiska Afrikainstitutet. Upsalla.

Rotimi, K., \& Ogen, O. (2008). Jaja and Nana in the Niger Delta Region of Nigeria: Proto-Nationalists or Emergent Capitalists. The Journal of Pan African Studies, 2, 48-56.

Gaudio, R. P. (1998). Male Lesbians and Other Queer Notions in Hausa. In S. O. Murray, 
\& W. Roscoe (Eds.), Boy-Wives and Female Husbands Studies of African Homosexualities (pp. 115-128). New York: Palgrave.

Taiwo, O. (2004). Ifa: An Account of a Divination System and Some Concluding Epistemological Questions. In K. Wiredu (Ed.), A Companion to African Philosophy (pp. 304-312). Hoboken, NJ: Blackwell.

Ukiwo. U. (2005). On the Study of Ethnicity in Nigeria (pp. 6-10). Working Paper 12, Centre for Research on Inequality, Human Security and Ethnicity, Department of International Development, Oxford: University of Oxford.

USAID (2006). Development and Governance Assessment of Nigeria (pp. 1-30).

Verran, H. (2001). Science and an African Logic. Chicago, IL: University of Chicago Press.

Woolman, D. C. (2001). Educational Reconstruction and Post-Colonial Curriculum Development: A Comparative Study of Four African Countries. International Education Journal, 2, 27-37. 
Submit or recommend next manuscript to SCIRP and we will provide best service for you:

Accepting pre-submission inquiries through Email, Facebook, LinkedIn, Twitter, etc. A wide selection of journals (inclusive of 9 subjects, more than 200 journals)

Providing 24-hour high-quality service

User-friendly online submission system

Fair and swift peer-review system

Efficient typesetting and proofreading procedure

Display of the result of downloads and visits, as well as the number of cited articles Maximum dissemination of your research work

Submit your manuscript at: http://papersubmission.scirp.org/

Or contact ojpp@scirp.org 